\title{
CORRESPONDENCE
}

\section{Three decades of occupational health research in South Wales}

Editor-The MRC Epidemiology Unit September, 1995 on the retirement of the director, Professor Peter Elwood. A small team will continue at Llandough Hospital, South Wales to complete work on current projects. The Epidemiology Unit (EU) originated as an offshoot of the MRC Pneumoconioses Research Unit (PRU) which pioneered epidemiological surveys among the coal mining and agricultural communities of South Wales. The EU was established in 1960 under the direction of Professor Archie Cochrane to conduct studies on a wider range of medical conditions. Peter Elwood joined the Unit in 1963 and succeeded Cochrane as director in 1974. Occupational research continued and EU workers have been involved in a wide range of studies over the past 35 years (table) and have authored or coauthored over 30 papers in this journal. ${ }^{1-32}$ The early papers of Elwood were based on a large study of textile workers in Northern Ireland undertaken in Professor John Pemberton's Department of Social and Preventive Medicine at Belfast.

In noting the closure of the Unit there are some lessons to be learnt from it's work. Large studies were undertaken by a small but highly committed team with local fieldworkers and working hours that suited the study population. This approach resulted in very high response rates. Their work also paid particular attention to identifying and examining exworkers as well as those currently employed. Based on the earlier studies at PRU standardised measures and questionnaires were used to reduce observer bias. The longevity of the unit meant that long term follow up studies could be undertaken to establish the prognostic signifi(South Wales) officially closed at the end of

cance of data obtained in the prevalence studies of occupational disease. Up to 1980 follow up relied upon local visiting; later mortality studies used the flagging service of the Medical Research Section of the Office of Population, Censuses, and Surveys at Southport, England. An interesting account of the early epidemiological surveys has been published elsewhere. ${ }^{33}$ Most of the data relating to the studies cited is still held at the former MRC unit. A mortality study of 1495 pest control officers has also just been completed. Further long term follow up of some of these cohorts could be considered in the future.

HUGH F THOMAS MRC Epidemiology Unit (South Wales),
Penarth, South Glamorgan CF64 2XW Penarth, South Glamorgan CF64 2XW

1 Higgins ITT, Cochrane AL. Chronic respiratory disease in a random sample of men and
women in the Rhondda Fach in 1958. $\mathrm{Br} f$ women in the Rhondda F
Ind Med 1961;18:93-102.

2 Cochrane AL. The attack rate of PMF. Br $\mathcal{F}$ Ind Med 1962;19:52-64

3 Higgins ITT, Oldham PD. Ventilatory capacity in miners; a five year follow up study. $\mathrm{Br}$ f Ind Med 1962;19:65-76.

4 Higgins ITT, Oldham PD, Kilpatrick GS, Drummond RJ, Bevan B. Blood groups in Drummond RJ, Bevan B. Blood groups in Br F Ind Med 1963;20:324-9.

5 Cochrane AL, Carpenter RG, Moore F, Thomas J. The mortality of miners and exminers in the Rhondda Fach. Br f Ind Med 1964;21:38-45.

6 Elwood PC, Cochrane AL, Benjamin IT, Seys-Prosser D. A follow up study of workers from an asbestos factory. $\mathrm{Br} \mathcal{F}$ Ind $\mathrm{Med}$ 1964;21:304-7.

7 Elwood PC, Pemberton J, Merrett JD, Carey GCR, McAulay IR. Byssinosis and other respiratory symptoms in flax workers in respiratory symptoms in flax workers in 27-37.

8 Elwood PC. Respiratory symptoms in men who had previously worked in a flax mill in Northern Ireland. $\mathrm{Br} \mathcal{F}$ Ind Med 1965;22: 38-42.

9 Cochrane AL, Thomas J, Clarke WG, Moore F. Changes in the prevalence of coalworkers pneumoconiosis among miners and ex-miners in the Rhondda Fach, 1951-61. Br $\mathcal{F}$ Ind Med 1965;22:49-57.

Some occupational health surveys associated with the MRC Epidemiology Unit (South Wales) 1960-95

\begin{tabular}{|c|c|c|c|c|}
\hline Population & $\begin{array}{l}\text { Number } \\
\text { eligible }\end{array}$ & $\begin{array}{l}\text { Outcome } \\
\text { measure }\end{array}$ & $\begin{array}{l}\text { Response } \\
\text { rate (\%) }\end{array}$ & $\begin{array}{l}\text { Duration of } \\
\text { follow up }(y)\end{array}$ \\
\hline $\begin{array}{l}\text { Rhondda men and women' } \\
\text { Miners and exminers }{ }^{2}\end{array}$ & $\begin{array}{r}800 \\
2165\end{array}$ & $\begin{array}{l}\mathrm{RS}, \mathrm{RM} \\
\mathrm{CXR}\end{array}$ & $\begin{array}{l}90 \\
93\end{array}$ & $\begin{array}{l}\mathrm{N} / \mathrm{A} \\
8\end{array}$ \\
\hline $\begin{array}{l}\text { Miners, exminers and } \\
\text { non-miners }\end{array}$ & & & & \\
\hline $\begin{array}{l}\text { non-miners } \\
\text { Miners and exminers }\end{array}$ & $\begin{array}{r}313 \\
1250\end{array}$ & $\begin{array}{l}\text { RM } \\
\text { Blood, saliva } \\
\text { RS, CXR }\end{array}$ & $\begin{array}{l}90 \\
92\end{array}$ & $\begin{array}{l}5 \\
\text { N/A }\end{array}$ \\
\hline $\begin{array}{l}\text { Miners, exminers and } \\
\text { non-miners }\end{array}$ & 9224 & CXR, RS, DC & 97 & 6 \\
\hline $\begin{array}{l}\text { Asbestos workers and } \\
\text { exworkers }\end{array}$ & 1422 & & & $<26$ \\
\hline Flax workers ${ }^{7}$ & 3066 & RS, RM & $\begin{array}{l}10 \\
82\end{array}$ & N/A \\
\hline Flax exworkers ${ }^{8}$ & 102 & RS, RM & 87 & N/A \\
\hline Pontypridd residents ${ }^{13}$ & 727 & SQ & 94 & N/A \\
\hline Steel workers ${ }^{14}$ & 1007 & SQ, eyes & 93 & $\mathrm{~N} / \mathrm{A}$ \\
\hline $\begin{array}{l}\text { Rhondda men }{ }^{16} \\
\text { Slate workers, exworkers }\end{array}$ & 6384 & DC & 99 & 20 \\
\hline $\begin{array}{l}\text { Slate workers, exworkers } \\
\text { and controls }{ }^{17}\end{array}$ & 1662 & RS, RM, CXR & 94 & N/A \\
\hline Miners and foundrymen ${ }^{18}$ & 387 & & $99 \cdot 5$ & 20 \\
\hline Miners and foundrymen ${ }^{19}$ & 369 & DC & 100 & 20 \\
\hline Flax workers ${ }^{20}$ & 2528 & DC & 97 & 16 \\
\hline Asbestos workers ${ }^{22}$ & 1592 & DC & 97 & $<41$ \\
\hline Rhondda $\mathrm{men}^{24}$ & 8526 & DC & 99.9 & 30 \\
\hline Flax exworkers ${ }^{27}$ & 2129 & $\mathrm{RS}, \mathrm{RM}$ & 90 & $\mathrm{~N} / \mathrm{A}$ \\
\hline Slate workers and controls ${ }^{28}$ & 1285 & DC & 100 & 6 \\
\hline Cotton exworkers ${ }^{29}$ & 1023 & $\mathrm{RS}, \mathrm{RM}$ & 87 & N/A \\
\hline Viscose rayon workers ${ }^{30}$ & 2939 & DC & 97 & $<37$ \\
\hline Painters and electricians ${ }^{32}$ & 3864 & DP, CR, DC & 88 & $<14$ \\
\hline
\end{tabular}

$\mathrm{N} / \mathrm{A}=$ not apaplicable; $\mathrm{RS}=$ respiratory symptom questionnaire; $\mathrm{RM}=$ respiratory measurements; $\mathrm{SQ}=$ symptom questionnaire; $C X R=$ chest $x$ ray film; $D C=$ death certificate; $D P=$ disability pension; $C R=$ cancer registration.
10 Carey GCR, Merrett JD, Elwood PC, Pemberton J, McAulay IR. Ventilatory capacity in flax workers in Nor

11 McCaulay IR, Carey GCR, Merrett JD, McClarin RH, Elwood PC, Pemberton J. A survey of dust concentrations in flax mills in
Northern Ireland. $\mathrm{Br} F$ Ind Med 1965;22: Northern.

12 Elwood PC, McAulay IR, McClarin RH, Pemberton J, Carey GCR, Merrett JD. Prevalence of byssinosis and dust levels in flax preparers in Northern Ireland. $\mathrm{Br} \mathcal{F}$ Ind Med 1966;23:188-93.

13 Taylor PJ, Pocock SJ, Hall SA, Waters WE. Headaches and migraine in colour retouchers. Br f Ind Med 1970;27:364-7.

14 Wallace J, Sweetnam PM, Warner CG, Graham PA, Cochrane AL. An epidemiological study of lens opacities among steel workers. Br f Ind Med 1971;28:265-71.

15 Waters WE, Cochrane AL, Moore F. Mortality in punctiform type of coalworkers pneumoconiosis. $B r f$ Ind Med 1974;31: 196-201.

16 Cochrane AL, Haley TJL, Moore F, Hole D. The mortality of men in the Rhondda Fach, 1950-70. Br F Ind Med 1979;36:15-22.

17 Glover JR, Bevan C, Cotes JE, Elwood PC, $e$ al. Effects of exposure to slate dust in North Wales. Br f Ind Med 1980;37:152-62.

18 Cochrane AL, Moore F. A 20 year follow up of men (aged 55-64) including coalminers and foundry workers in Staveley, Derbyshire. Br f Ind Med 1980;37:226-9.

19 Cochrane AL, Moore F. A 20 year follow up of a population sample (aged 25-34) including coalminers and foundry workers in Staveley, Derbyshire. $\mathrm{Br} \mathcal{F}$ Ind Med 1980; 37:230-3.

20 Elwood PC, Thomas HF, Sweetnam PM Elwood JH. Mortality of flax workers. $\mathrm{Br}$ Ind Med 1982;39:18-22.

21 Cochrane AL, Moore F, Moncrieff CB. Are coalminers with low risk factors for ischaemic heart disease at greater risk of developing progressive massive fibrosis? $\mathrm{Br} \mathscr{f}$ Ind Med 1982;39:265-8.

22 Thomas HF, Benjamin IT, Elwood PC Sweetnam PM. Further follow up study of workers from an asbestos cement factory. $\mathrm{Br}$ f Ind Med 1982;39:273-6.

23 Cochrane AL, Moore F. Lung mechanics in relation to radiographic category of coalworkers' simple pneumoconiosis. $\mathrm{Br} f$ Ind Med 1984;41:284-5.

24 Atuhaire LK, Campbell MJ, Cochrane AL, Jones M, Moore F. Mortality of men in the Rhondda Fach 1950-80. Br 7 Ind Med 1985;42:741-5.

25 Atuhaire LK, Campbell MJ, Cochrane AL, Jones $M$, Moore $F$. Gastric cancer in a
South Wales valley. $B r \mathcal{F}$ Ind Med 1986;43: South 2 .

26 Atuhaire LK, Campbell MJ, Cochrane AL, Jones M, Moore F. Specific causes of death in miners and ex-miners in the Rhondda Fach 1950-80. Br $\mathcal{F}$ Ind Med 1986;43: 497-9.

27 Elwood JH, Elwood PC, Campbell MJ, Stanford CF, et al. Respiratory disability in ex-flax workers. $B r f$ Ind Med 1986;43: ex-flax

28 Oldham PD, Bevan C, Elwood PC, Hodges NG. Mortality of slate workers in North Wales. Br f Ind Med 1986;43:550-5.

29 Elwood PC, Sweetnam PC, Bevan C Saunders MJ. Respiratory disability in excotton workers. $\mathrm{Br} F$ Ind $\mathrm{Med}$ 1986;43 $580-6$.

30 Sweetnam PM, Taylor SWC, Elwood PC. Exposure to carbon disulphide and ischaemic heart disease in a viscose rayon factory. BrF Ind Med 1987;44:220-7.

31 Elwood PC. Cotton workers and the Manchester criteria. $\mathrm{Br} \mathcal{F}$ Ind Med 1988;45. 431-2.

32 Guberan E, Usel M, Rauymond L, Tissot $R$ Sweetnam PM. Disability, mortality and incidence of cancer among Geneva painters incidence of cancer among and electricians: a historical prop
study. $B r$ Ind Med 1989;46:16-23.

33 Cochrane AL, Blythe M. One man's medicine. London: BMJ (Memoir Club). 1989.

Occupational medicine: the way ahead

Editor-Seaton and Agius describe clearly the evolution of occupational medicine to its present position in your August Journal. We agree, in general, with their analysis. The way ahead that they seek involving an 